\title{
A busca de inteligibilidade na cultura brasileira: fragmentos de um retrato evolutivo
}

\author{
The quest for intelligibility in Brazilian culture: \\ fragments of an evolutional portrait
}

Ricardo Waizbort

Programa de Pós-Graduação em História das Ciências da Saúde, Fundação Oswaldo Cruz

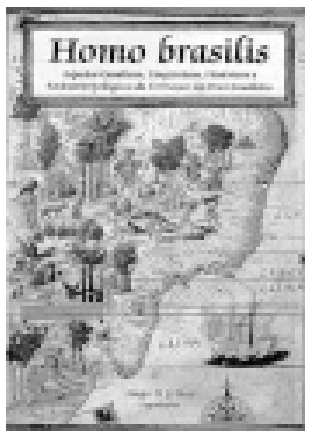

Sérgio J. Pena (org.) Homo brasilis: aspectos genéticos, lingüísticos, bistóricos e

socioantropológicos da formação do povo brasileiro,

Ribeirão Preto, FUNPEC-RP, 2002, 192p.
És samba e jongo, xiba e fado, cujos Acordes são desejos e orfandades De selvagens, cativos e marujos; E em nostalgias e paixões consistes Lasciva dor, beijo de três saudades, Flor amorosa de três raças tristes. Olavo Bilac, Música brasileira
A descoberta, em 1953, da estrutura físico-química do DNA e, conseqüentemente, do gene, abriu possibilidades antes inimagináveis para vários campos do conhecimento sobre a vida. Da zoologia à botânica, da fisiologia à embriologia, da paleontologia à microbiologia, da anatomia à medicina, da biogeografia à evolução, da etologia à psicologia etc. — todas essas ciências receberam substanciais impulsos uma vez que a comparação entre a linguagem dos genes das mais diferentes espécies e variedades tornou-se acessível. O estudo sobre a formação das populações humanas (da espécie Homo sapiens) também sofreu essa influência. Como as populações humanas fazem parte de uma espécie biológica, os DNAs contidos nas células humanas podem ser analisados a partir de técnicas e conceitos moleculares com vistas a descrever e compreender melhor a constituição e formação genética de cada um dos diferentes tipos de população humana que povoaram e povoam este planeta.

O livro Homo brasilis, organizado pelo dr. Sérgio Danilo Pena, renomado geneticista da Universidade Federal de Minas Gerais (UFMG), estrutura-se em torno do debate que redundou dos resultados e conclusões do próprio organizador, e de seus colaboradores, acerca da formação biológica de uma fração do povo brasileiro. Sérgio Pena utilizou ferramentas da genética molecular e da genética de populações para investigar, através de marcadores moleculares (os DNAs da mitocôndria e do cromossomo Y), as linhagens genealógicas das populações sabidamente reconhecidas como formadoras do povo brasileiro: as raças ${ }^{1}$ branca (ibérica), negra (africana) e índia (ameríndia).

\footnotetext{
${ }^{1} \mathrm{O}$ conceito de raça pode ser definido como uma variedade ou subdivisão dentro de uma espécie: raças seriam subespécies. Na metade do século XX, os biólogos tenderam a abandonar o conceito de raça em favor do conceito de população. Para uma apresentação e discussão sobre essa modificação, ver Ricardo Ventura Santos (1996). Na presente resenha, intercambiarei livremente os dois conceitos, entendendo que ambos representam subdivisões de uma espécie que podem apresentar diferenças tanto morfológicas como comportamentais.
} 
Desde o início, Sérgio Pena admite que seus achados corroboram estudos socioantropológicos de renomados personagens da literatura nacional, como Paulo Prado, autor de Retrato do Brasil (1927), Sérgio Buarque de Holanda, de Raizes do Brasil (1933), Gilberto Freyre, de Casa-grande e senzala (1933) e Darcy Ribeiro, de O povo brasileiro (1995). Segundo Sérgio Pena, esses escritores "usando metodologia histórica, sociológica e antropológica já analisaram as origens do povo brasileiro" (p. 11).

No ano de 2000, no Congresso Brasileiro de Genética, Sérgio Pena apresentou os resultados de seus trabalhos sobre a composição genética de grupos de cidadãos brasileiros, mulheres e homens, que se autodenominam 'brancos', depois de haver investigado o DNA dos cromossomos $\mathrm{Y}$ e o DNA das mitocôndrias desses indivíduos. ${ }^{2} \mathrm{O}$ DNA extracromossômico das mitocôndrias e o DNA sexual do cromossomo Y são importantes indicadores de variações naturais na população, no nível molecular dos ácidos nucleicos. As moléculas de DNA contidas nessas estruturas são excelentes marcadores de variações (mutações) que apareceram nas populações e de suas seqüências evolutivas. Essas variações, portanto, podem ser tomadas como índices de distância evolutiva entre grupos, ou seja, informações sobre o grau de parentesco filogenético entre populações.

Segundo Sérgio Pena, o DNA dos cromossomos Y dos sujeitos brancos investigados tinha predominantemente origem portuguesa na linhagem masculina (patrilinhagem). Quanto à linhagem feminina (matrilinhagem), os brasileiros autodenominados brancos eram predominantemente não-brancos, ou seja, o DNA das mitocôndrias de homens e mulheres brancos era uma mistura de DNAs de linhagens negras, índias e brancas. Generalizando os achados de Sérgio Pena poder-se-ia dizer que, em média, as mitocôndrias que você, leitor brasileiro, carrega dentro de suas células, independentemente do seu gênero, masculino ou feminino, é uma mistura das linhagens genealógicas ameríndias, ibéricas e africanas. Dito de forma menos eufemística, isso significa que, para a formação atual do povo brasileiro branco, colaborou muito o fato bastante comum de os portugueses senhores de terras terem filhos com índias e sobretudo com negras, em contraposição à pouca freqüência com que africanos ou índios tinham filhos com mulheres brancas. Parece óbvia a carga de violência histórica que essa conclusão implica.

Em Homo brasilis, Sérgio Pena reuniu em torno de uma versão atualizada de seu artigo, 'Retrato molecular do Brasil' - originalmente publicado na revista de divulgação científica Ciência Hoje (abr. 2000)

\footnotetext{
${ }^{2}$ Espermatozóides masculinos e óvulos femininos são os veículos que transmitem a informação genética de geração a geração, de pais para filhos. Os cromossomos Y são transmitidos apenas pelos pais enquanto as mitocôndrias, os DNAs contidos nas mitocôndrias, são transmitidas quase que exclusivamente pelas mães. As fêmeas da espécie humana não possuem cromossomos Y em suas células. Assimetricamente, os machos de nossa espécie possuem mitocôndrias em suas células. Todavia, o número de mitocôndrias na cabeça de um espermatozóide é desprezível, se comparado ao número de mitocôndrias encontradas no citoplasma de um óvulo. Nesse contexto, a informação genética feminina transmitida pelas mitocôndrias é chamada matrilinhagem. A informação genética masculina transmitida pelo cromossomo Y é chamada patrilinhagem.
} 
- nove escritos que apresentam e discutem certos aspectos genéticos, lingüísticos, históricos e socioantropológicos da formação do povo brasileiro, como se lê no subtítulo da obra. No prefácio do livro, Sérgio Pena afirma "que o Brasil representa um verdadeiro ponto de encontro". Buscando responder à pergunta 'quem é o brasileiro atual?', o geneticista sugere a mistura harmoniosa das raças como solução para o problema da formação do nosso povo e pretende que seu livro, certamente multidimensional, seja "um outro ponto de encontro, filogeográfico, de geneticistas, antropólogos, historiadores e lingüistas". Seu propósito é "simplesmente descrever e celebrar a diversidade", refutando categoricamente a concepção de raças humanas como categorias biológicas válidas.

Essa otimista tentativa de celebrar uma diversidade harmoniosa despertou, talvez não sem motivo, ódio e ressentimento de cidadãos cujo passado fora violentamente alterado pelo espírito imperialista do homem branco europeu. Além disso, Sérgio Pena acaba incorrendo no que o filósofo David Hume, no século XVII, chamaria de 'falácia naturalista', pois sugere uma conclusão moral que não decorre de suas premissas factuais: o reconhecimento das elites brancas de que são formadas também por DNAs africano e ameríndio deveria ser suficiente para abrir suas mentes, nelas despertando uma espécie de solidariedade em relação aos necessitados. Mas crer que uma invisível entidade molecular, de que não temos vivência imediata, da qual tomamos conhecimento apenas mediada por teorias e outros instrumentos conceituais, possa alterar a consciência de quem quer que seja é no mínimo uma enorme ingenuidade fenomenológica, como muito bem assinalam Ventura Santos e Maio no último artigo do livro. Creio que as conclusões de Sérgio Pena, no entanto, não diminuem a importância de Homo brasilis como um todo. Antes de mais nada, Homo brasilis é uma audaciosa tentativa de discutir a formação de nosso país sob vários pontos de vista. Além disso, os resultados obtidos por Sérgio Pena sugerem que as genéticas molecular e de populações estão se tornando instrumentos importantíssimos na reconstrução de nosso passado histórico e na construção de nossa identidade nacional.

Todavia, os dez artigos que compõem Homo brasilis apresentam grande heterogeneidade - o que talvez possa ser compreendido se discriminarmos os escritos que estariam mais próximos de uma idealizada ciência natural e os que estariam mais próximos de uma também idealizada ciência social. Essa classificação é algo arbitrária, mas um rápido manuseio da obra permite constatar que, de um modo geral, os seis primeiros artigos, incorporando os aspectos genéticos, lingüísticos e históricos da formação do povo brasileiro, estão coalhados de figuras, tabelas e gráficos. A última parte, os aspectos socioantropológicos, faz uso de recursos iconográficos apenas em três ocasiões, sendo que em todas elas trata-se de uma foto (e nenhuma figura, tabela ou gráfico), salvo a última que é uma fotografia de um quadro de arte, A redenção de Can, de Modesto Brocos y Gomes, de 1895, obra muitas vezes interpretada como a representação do embranquecimento do povo brasileiro em três gerações. A redenção de Can também foi reproduzido como capa de outra importante 
coletânea de artigos sobre a questão da raça na formação da identidade do Brasil: o livro Raça, ciência e sociedade, organizado por Marcos Chor Maio e Ricardo Ventura Santos.

Homo brasilis tem um nível acadêmico altíssimo, o que faz com que nem sempre os leitores encontrem textos livres de tecnicismos. Os últimos quatro artigos, incluídos na seção 'Aspectos socioantropológicos', são mais acessíveis aos leitores não especializados nas metodologias das genéticas molecular e de populações. O último artigo, escrito em parceria por Ricardo Ventura Santos e Marcos Chor Maio, apresenta ampla contextualização das controvérsias que se seguiram à publicação da primeira versão de 'Retrato molecular do Brasil'. O trabalho de Santos e Maio poderia ser lido primeiro por quem deseja compreender melhor o contexto histórico, social, antropológico e político em que se inscreve o problema que Sérgio Pena desenvolveu em seu polêmico artigo.

Como sugere o texto de Santos e Maio, Sérgio Pena realmente parece querer ressuscitar o mito da democracia racial no Brasil. Esse modelo da formação do povo brasileiro teria atingido seu ponto mais alto com Casa-grande e senzala, de Gilberto Freyre, publicado em 1933, que tenta apresentar o país como uma mistura algo harmoniosa entre as raças branca e negra. Como enfatiza o artigo de Marcos Chor Maio, vários cientistas sociais e naturais trabalharam, entre o final da década de 1940 e início da de 1950, na Organização Educacional, Científica e Cultural das Nações Unidas (Unesco), na formulação de dois conceitos de raça: o primeiro mais próximo conceitualmente das ciências sociais, o segundo mais próximo das ciências naturais, mas ambos essencialmente anti-racistas. Pela militância de Artur Ramos e outros atores na Unesco, em fins da década de 1940 e início da de 1950, o Brasil teria sido 'descoberto' como um laboratório no qual a experiência natural de intercruzamento das raças havia atingido seu mais alto grau de sucesso. Assim, o Brasil foi considerado, em meados do século XX, um campo privilegiado para o estudo das raças humanas. Entretanto, como Santos e Maio mostram, Florestan Fernandes foi um dos primeiros a desafiar a concepção de que o Brasil era uma democracia racial nos moldes freyrianos (p. 181).

Em outro artigo dessa mesma seção, Jair de Souza Ramos argumenta que, desde o período colonial - com o 'estatuto da pureza do sangue' (p. 133) - até a chamada 'teoria do branqueamento', o pensamento social brasileiro trabalhou com a noção de que, para 'melhorar' o povo brasileiro e transformar nosso país em uma nação seria necessário, de uma forma ou de outra, cultivar a raça branca, pois ela representaria o ápice de civilidade: seja porque as raças negra e índia seriam inferiores no que diz respeito à sua constituição física (genética), seja porque essas raças eram as que pareciam estar naturalmente mais sujeitas a certos males endêmicos que assolavam sobretudo o interior do país. Mas, a uma certa altura da história, ao invés de se valorizar meramente o homem branco, a cultura e a política brasileira passaram a valorizar a mistura. Jair de Souza procurar alertar o leitor, no entanto, para o fato de que valorizar a miscigenação, como no caso de Gilberto Freyre, não significa estabelecer igualdade entre as raças. 
Focalizando o Museu Nacional do Rio de Janeiro entre o final do século XIX e início do XX, Ricardo Ventura Santos procura compreender, entre outras coisas, como ocorreu nesse período a desqualificação dos mestiços e a classificação dos não-europeus nos níveis mais baixos da hierarquia das raças humanas. Ao longo do trabalho, busca demonstrar como, no Museu Nacional entre 1870 e 1930, a antropologia física esteve vinculada ao clima social e político da época em que foi gerada, apresentando sobretudo as obras dos médicos e antropólogos João Baptista Lacerda e Edgard Roquette-Pinto.

Assim, os artigos que compõem a seção 'Aspectos socioantropológicos' de Homo brasilis procuram mostrar que o surgimento da idéia de identidade nacional no Brasil esteve imbricado com questões relativas à ciência como marca de modernidade e, em especial, com a idéia de que era possível 'melhorar' o povo brasileiro através de medidas eugênicas e com isso construir uma idéia de nação, sobretudo branca e saudável, que se adequasse à concepção de vários países estrangeiros, incluindo os Estados Unidos, a França, a Alemanha e a Inglaterra. Nesse processo, negros e índios eram considerados indivíduos pertencentes a raças inferiores, das quais o país deveria se purgar para galgar os estágios mais altos de civilidade. Gostaria de ressaltar, apenas de passagem, que as medidas eugênicas e muitas vezes racistas sugeridas e adotadas por nossos cientistas, políticos e governantes no mais das vezes traziam em seu bojo conceitos ligados ao lamarckismo e ao neolamarckismo, especialmente a noção de herança dos caracteres adquiridos, segundo a qual o meio ambiente 'instruía' as modificações necessárias para adequação dos corpos e populações às circunstâncias do entorno. Talvez não fosse preciso assinalar que essa maneira de ver as variações das populações é contrária ao modo de ver darwinista, que diz que o meio ambiente não instrui as modificações, mas apenas seleciona variações previamente existentes nas populações.

Mencionei anteriormente que o último texto do livro, o artigo de Santos e Maio, talvez devesse ser lido primeiro por aqueles que desejassem ter uma idéia geral acerca do debate sobre o retrato molecular do Brasil e o mito da democracia racial. Afirmo agora que os leitores que procuram os argumentos genéticos e evolutivos acerca da formação do povo brasileiro talvez devessem começar o livro não pelo primeiro trabalho, o do próprio Sérgio Pena, mas pelo terceiro, escrito em parceria por Fabrício dos Santos e Eduardo Tarazona-Santos. Esses autores tratam de apresentar, de forma bem mais clara do que nos dois artigos que o antecedem, uma explicação, tanto científica e histórica quanto metodológica, das questões envolvidas em caracterizar populações que são resultado do fluxo de genes entre populações que estavam cronologicamente afastadas por muitos séculos, no caso as populações de brancos europeus e de índios americanos (e depois as populações negras) - populações que passaram a estabelecer uma intensa troca de genes, sobretudo depois da chegada dos europeus às Américas a partir de $1492 \mathrm{e}$, posteriormente, com a importação de escravos negros. O texto de Santos e Tarazona-Santos indica também, em consonância com os artigos anteriores, que as populações 
brasileiras, modernas, urbanas, ditas de cor branca, apresentam linhagens maternas com um alto componente ameríndio (e/ou africano), enquanto as linhagens paternas são predominantemente européias. Isso seria devido "a comportamentos migratórios e matrimoniais diferenciados entre os dois sexos das distintas populações originais" (p. 52).

O trabalho de Antonio Amorim investiga as histórias das linhagens masculina (DNA do cromossomo Y) e feminina (DNA das mitocôndrias) e conclui que são inteiramente distintas. Segundo o autor, "enquanto existe uma significativa proporção de influxo gênico subsaariano nas linhagens femininas, ele está ausente ... nas linhagens masculinas" (p. 38). Segundo Amorim, a interpretação mais plausível residiria no fato de que "enquanto os descendentes dos cruzamentos entre os portugueses e escravas existiram e deixaram descendência, o cruzamento recíproco ou não existiu ou não deixou frutos em número detectável". O artigo escrito em parceira por Vania Prado e Juliana Alves-Silva é um estudo complementar ao anterior, investigando a variabilidade do DNA mitocondrial de populações indígenas. As autoras apresentam detalhes de seu método de estudo do DNA mitocondrial, que é tratado com proteínas conhecidas como 'enzimas de restrição', capazes de indicar mutações ocorridas nos DNAs das populações estudadas. O resultado desses estudos confirma mais uma vez que a população brasileira, sob um ponto de vista biológico, formou-se através de uma intensa fusão de genes originados de três grupos principais: o europeu colonizador, as populações nativo-americanas que estavam presentes no território brasileiro há milhares de anos, e os africanos que foram deslocados para o Brasil durante mais de três séculos de tráfico de escravos. As autoras concluem o trabalho ressaltando que o estudo de pessoas brancas pode nos dar pistas importantes sobre a história e a variabilidade dos genes ameríndios cujos veículos originais estão hoje praticamente extintos ou reduzidos a números não significativos, em contraste com a diversidade de populações indígenas de várias tribos distintas que habitavam o Brasil antes da chegada dos colonizadores.

A segunda e a terceira partes de Homo brasilis são compostas de apenas um ensaio cada. A seção intitulada 'Aspectos lingüísticos' contém o artigo escrito por Denny Moore e Luciana Storto. As autoras indicam que embora não haja uma correlação direta entre cultura, língua e genes, as hipóteses sobre o passado levantadas a partir de estudos lingüísticos podem ser contrastadas com hipóteses genéticas e culturais na tentativa de construir um quadro menos fragmentário da filogenia humana. Mecanismos de mudança lingüística, como, por exemplo, a mudança fonética, podem ser investigados por métodos comparativos que se valem de variações do som de certas palavras entre populações genealogicamente relacionadas. A comparação de traços fonéticos entre populações e subpopulações é uma forte ferramenta para inferir as relações filogenéticas entre elas, ou seja, quais fonemas são primários e quais são derivados, o que permite identificar as populações descendentes e as ascendentes. A partir dessas comparações entre sons podem ser estabelecidas correspondências 
fonéticas, cognatos, famílias e troncos lingüísticos. Já o único texto da terceira parte de Homo brasilis, 'Aspectos históricos' foi escrito por Herbert S. Klein. O artigo é uma contribuição historiográfica importantíssima, pois trata-se de uma extensa e rigorosa apresentação de dados da exportação de negros da África e de sua importação por vários países do mundo, do século XV ao XIX, com ênfase especial no Brasil e nas particularidades da recepção dos africanos em terras brasileiras.

Como afirmei anteriormente, creio que a conclusão pretendida por Sérgio Pena em seu artigo incorre em uma espécie de falácia naturalista. O geneticista sugere que os resultados poderiam servir para que as elites reconhecessem sua comunhão genética com os menos favorecidos. Mas não se deve confundir o reino do 'ser' da natureza com o reino do 'deve ser' da moral e da cultura, nos ensinou David Hume. O que a genética humana brasileira descobriu, e que a sociologia já sabia, é que a formação do nosso povo se deve preponderantemente à fusão das três raças 'tristes' (ver o último verso de Bilac na epígrafe desta resenha). Mas tal miscigenação não fez as diferenças de cor e de classe desaparecerem por completo. E dizer que as raças humanas não existem, de um ponto de vista biológico, sem outras qualificações, pode ser interpretado como se o próprio conceito de raça estivesse sendo posto em xeque. O fenômeno das raças como subdivisões de uma espécie vai muito além do conhecimento humano sobre as raças humanas. O conceito de raças de animais e variedades de plantas remonta aos gregos, embora só a partir do final do século XVII tenha começado a ser sistematizado.

Mas o raciocínio de Sérgio Pena está correto quando, no prefácio de Homo brasilis, afirma que "não houve tempo suficiente para sua formação (das raças humanas) e, agora, com a enorme mobilidade geográfica humana, nunca irá acontecer" (p. v). Se as variedades (raças) são espécies incipientes, como assinalava Darwin já em 1859, a ausência de barreiras físicas e as conseqüentes migrações não permitem que diferenças genéticas, geradas estocasticamente e selecionadas pelas circunstâncias ambientais, possam se acumular na espécie humana. Entretanto, a percepção das diferenças, sobretudo morfológicas (mas também culturais e intelectuais), entre os homens, tem chamado a atenção desde que existem registros históricos, pois, ao que tudo indica, o deslocamento geográfico de homens e grupos foi uma constante no nosso passado recente e evolutivamente distante. Dessa forma, o encontro entre culturas distintas, e o reconhecimento de suas diferenças, dificilmente é uma novidade de nossos tempos.

Do conjunto de textos que perfazem Homo brasilis, parece ficar claro que o processo de miscigenação entre as raças, embora importantíssimo para a formação do povo brasileiro, não pode ser considerado pacífico ou harmonioso. A beligerância ibérica, que praticamente varreu as populações indígenas do território brasileiro, e o verdadeiro seqüestro em massa dos africanos de suas tribos revelam um alto grau de violência histórica. Porém, no meu entendimento, a história da formação de um povo, de uma nação, é um processo aberto, e seus caminhos, evolutivo (biológico) e cultural (sociológico), se separam apenas com muita dificuldade. Theodosius Dobzhansky, geneticista que trabalhou na Universidade de São Paulo (USP) em meados do século 
XX, em artigo publicado em 1973, afirmou que na biologia nada faz sentido senão à luz da evolução. Do ponto de vista biológico, evolução não significa necessariamente progresso, embora em condições naturais, sem intervenção humana, a seleção natural tenda a produzir designs melhores, progressivos, em relação ao passado, desde que o ambiente não se altere de forma drástica. Portanto, não faz sentido falar em espécies melhores e piores sem fazer referências explícitas às condições ambientais, que são necessariamente temporais. A sobrevivência dos mais aptos, idéia de Herbert Spencer, e não de Darwin, parece se referir a um critério de aptidão circular e independente do tempo, o que significa dizer, erroneamente, que poderia haver indivíduos mais aptos em todas as circunstâncias. Assim, falar de povos ou raças mais avançados e mais atrasados não teria significado em sentido absoluto, mas apenas em referência a um determinado ponto de vista, de novo necessariamente ecológico e histórico. O que ocorre no caso brasileiro, como apontam Santos e Maio no último artigo de Homo brasilis, seguindo outros autores, é um choque entre taxonomias, devido à complexidade do sistema de classificação racial. Nosso país certamente é racial e culturalmente hỉbrido. Isso não significa que historicamente negros e índios tenham sido tratados dignamente, muito pelo contrário. O dualismo senhor/escravo, branco/negro, tem um travo de cor em nossas terras que se opõe ao travo de origem que afeta primordialmente o choque de raças nos Estados Unidos.

Permita-me o leitor concluir essa resenha parafraseando um episódio de Memórias póstumas de Brás Cubas, de Machado de Assis, publicado em 1881. No capítulo 21, 'O almocreve', o defunto narrador, Brás Cubas, narra um episódio em que ele mesmo contracenou com um sujeito que cuidava de mulas, um almocreve. A ação se passa no final do século XIX no Rio de Janeiro. No episódio referido, o narrador quase é morto quando, ao tentar montar um cavalo, o animal bate em retirada com riscos de jogar sua montada em um precipício. Brás Cubas é salvo pelo almocreve. O narrador lembra que naquela ocasião tinha cinco moedas de ouro na sua algibeira, e resolve imediatamente dar três ao homem que salvou sua vida. Não que sua própria existência valesse apenas três moedas de ouro, sua vida não tinha preço. Mas três moedas lhe pareceram uma recompensa justa. Logo, porém, vendo a humildade do homem que o salvou — o qual, em determinado momento, beija o focinho do quadrúpede —-, resolve diminuir a recompensa para uma moeda de ouro. Ao fim do episódio, encontramos o narrador dando apenas uma moeda de prata ao pobre miserável. E qual não é nosso sorriso amarelo quando Brás Cubas raciocina, arrependido, que o almocreve não fez mais que sua obrigação, e que uma mísera moedinha de cobre haveria de recompensálo por completo; que o ato de dar aquela moeda de prata acabou por ser um desperdício, dados o estado de penúria e a humildade do seu salvador.

Agora eu pergunto aos que me acompanharam até aqui: leitor, mesmo sem ter dado uma descrição do almocreve, mesmo sem possuir a verve de Machado de Assis, você imaginou o almocreve, enquanto eu apresentava o episódio, como um homem branco? Nosso travo de cor reside nisso: que pensamos em termos da oposição entre senhor e escravo, entre rico e pobre, sendo a oposição entre branco e negro (ou índio, ou mulato, ou mameluco) apenas um traço de uma chave maior. Ao contrário dos Estados Unidos, não temos um racismo de origem, mas um racismo de traço, como indicam Santos e Maio, sendo que na maior parte das vezes a cor é um 
Agradeço a

Maria Rosa Lopez Cid, aluna de mestrado do curso de pós-graduação em história das ciências das saúde, da COC/ Fiocruz, que gentilmente fez uma revisão da resenha. traço do passado escravo e pobre. Machado de Assis brinca com essas posições fazendo o leitor se constranger com o arrependimento de Brás Cubas, enquanto na verdade está adulando o leitor com uma espécie de volubilidade de pensamentos morais típicos da modernidade literária, tocando assim nas feridas de uma espécie de discriminação talvez mais profunda: a discriminação dos donos de terra e proprietários dos meios de produção em relação aos seus empregados.

\section{REFERÊNCIA BIBLIOGRÁFICA}

Santos, Ricardo Ventura 'Da morfologia às moléstias, de raça à população: trajetórias conceituais em 1996 antropologia física no século XX'. Em Marcos Chor Maio e Ricardo Ventura Santos, Raça, ciência e sociedade. Rio de Janeiro, Fiocruz/CCBB, pp. 125-40.

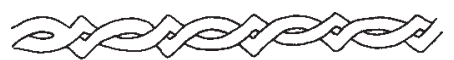

